\title{
1.2.1.1 Harvest, Collection and Storage Quarter 3 Milestone Report
}

Lynn Wendt, Kara Cafferty, William Smith, lan Bonner, Qiyang Huang, Rachel Colby

July 2014

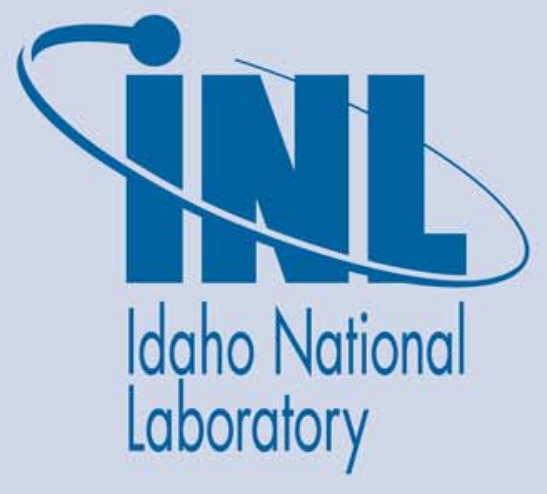

The INL is a U.S. Department of Energy National Laboratory operated by Battelle Energy Alliance 


\title{
1.2.1.1 Harvest, Collection and Storage Quarter 3 Milestone Report
}

\author{
Lynn Wendt, Kara Cafferty, William Smith, lan Bonner, \\ Qiyang Huang, Rachel Colby
}

July 2014

\author{
Idaho National Laboratory \\ Idaho Falls, Idaho 83415
}

http://www.inl.gov

Prepared for the

U.S. Department of Energy

Office of Energy Efficiency and Renewable Energy

Under DOE Idaho Operations Office

Contract DE-AC07-05ID14517 


\begin{tabular}{|l|l|}
\hline $\begin{array}{l}\text { ID\#: INL WBS 1.2.1.1 } \\
\text { Type: Regular }\end{array}$ & $\begin{array}{l}\text { Completion Date: July 31, 2014 } \\
\text { Scheduled Completion: June 30, 2014 }\end{array}$ \\
\hline Milestone Title: & $\begin{array}{l}\text { Complete evaluation of three corn stover storage systems capable of } \\
\text { preserving dry matter and quality of high-moisture }(>30 \%) \text { stover to } \\
\text { meet specifications of dry matter loss }(<15 \%) \text {, conversion efficacy } \\
(>90 \% \text { of available sugars) and minimize downstream preprocessing } \\
\text { costs. This milestone will compare conventional dry baled storage, } \\
\text { ensiling (bunker and tube), and bale wrapping systems. }\end{array}$ \\
\hline Authors: & $\begin{array}{l}\text { Lynn Wendt, Kara Cafferty, William Smith, Ian Bonner, Qiyang } \\
\text { Huang, Rachel Colby }\end{array}$ \\
\hline Project Name: & $\begin{array}{l}\text { Biomass Engineering-1.2.1.1 Harvest, Collection, \& Storage; Award } \\
\text { Number 15076 } \\
\text { J. Richard Hess }\end{array}$ \\
Project Leader: & $\begin{array}{l}\text { Biomass, supply chain, single-pass harvest, storage, moisture, ensiling, } \\
\text { bale wrap }\end{array}$ \\
\hline Key Words: & $\begin{array}{l}\text { This report contains business sensitive and/or potential intellectual property information. Written permission from the } \\
\text { author must be obtained prior to distribution beyond Laboratory and DOE staff. }\end{array}$ \\
- This milestone report will be converted into a publicly available Laboratory technical report. \\
- Information in this report will be the subject of a subsequent journal article submission.
\end{tabular}

\section{Executive Summary}

Single pass baling of corn stover is required in order to meet targets for the herbaceous biomass 2017 logistics design case. Single pass stover harvest occurs during the grain harvest and generally results in stover with a moisture content of 30-50\% wet basis (w.b). Aerobic storage of corn stover with high moisture results in high levels of dry matter loss (DML), up to $25 \%$. Anaerobic storage (ensiling) reduces DML to less than 5\%, but additional costs are associated with handling and transporting the extra moisture in the biomass. This milestone provides a best-estimate of costs for using high moisture feedstock within the conventional baled logistics system. The costs of three (3) anaerobic storage systems that reduce dry matter losses (bale wrap, silage tube, and silage drive over pile) are detailed in this milestone and compared to both a conventional dry-baled corn stover case and a high moisture bale case, both stored aerobically. The total logistics cost (harvest, collection, storage, and transportation) of the scenarios are as follows: the conventional multi-pass dry bale case and the single-pass high moisture case stored aerobically were nearly equivalent at $\$ 61.15$ and $\$ 61.24$ DMT. The single-pass bale wrap case was the lowest at $\$ 57.63 / \mathrm{DMT}$. The bulk anaerobic cases were the most expensive at $\$ 84.33$ for the silage tube case and $\$ 75.97$ for the drive over pile, which reflect the additional expense of transporting highmoisture bulk material; however, a reduction in preprocessing costs may occur because these feedstocks are size reduced in the field. In summary, the costs estimates presented in this milestone report can be used to determine if anaerobic storage of high-moisture corn stover is an economical option for dry matter preservation. 


\section{Purpose and Scope}

Anaerobic storage of high moisture biomass is capable of consistently producing feedstock that suffers minimal dry matter loss in storage. This in an attractive option for conditions that do not support dry aerobic storage; however, there are cost implications in the rest of the feedstock logistics system. The overall goal of this milestone is to provide a cost estimate for harvesting, collecting, storing, and transporting high-moisture corn stover to a biorefinery in cases when the conventional dry bale system would suffer high dry matter loss. The analysis compares high-moisture bale and bulk feedstock operations using INL's Biomass Logistics Model. These specific operations with bulk feedstocks—not routinely considered within our baled herbaceous feedstock supply system — will be added or updated with the best-available data for use within the model.

Past studies, including field studies performed through collaboration between INL and AGCO, have demonstrated that aerobic storage of high moisture corn stover bales $(\mathrm{mc}=49 \%$, wb) causes self-heating due to microbiological activity (Figure 1), resulting in dry matter losses to bales in the range of 7-26\% over the course of 9 months (Figure 2).

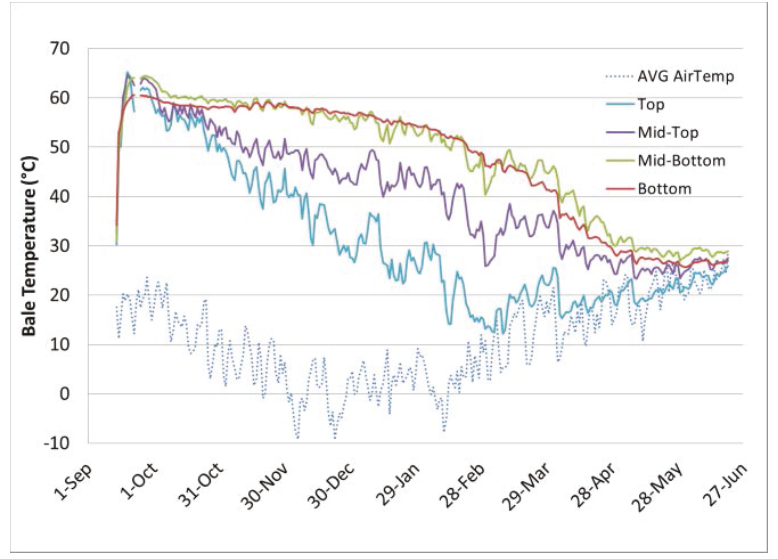

Figure 1. Daily average temperature measurements for four different bale positions within 4-high stack

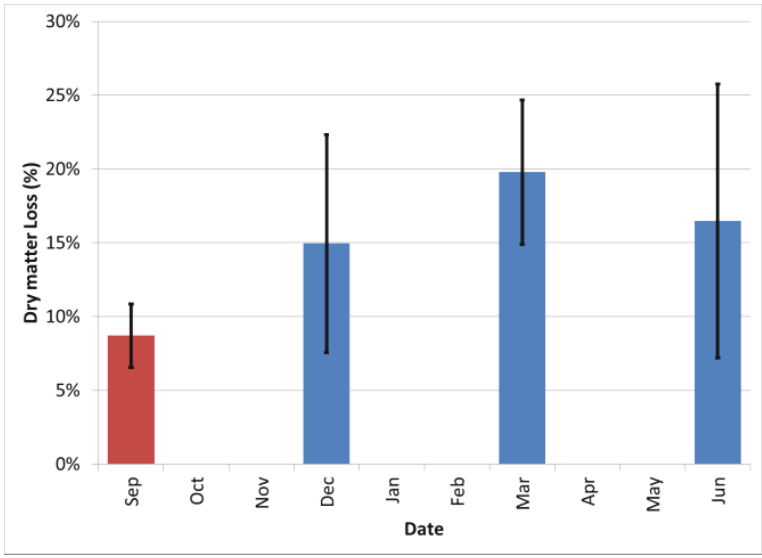

Figure 2. Average ( $n=12 \pm 1 S D)$ dry matter losses in stacked bales throughout storage; the red bar represents two weeks of dry matter loss from fieldstored bales 
Likewise, INL storage reactors have shown that loses can exceed $25 \%$ during aerobic storage of 50\% moisture corn stover (Figure 3). In the same study, storage reactors receiving reduced oxygen sustained only $10 \%$ DML during the self-heating period [1].

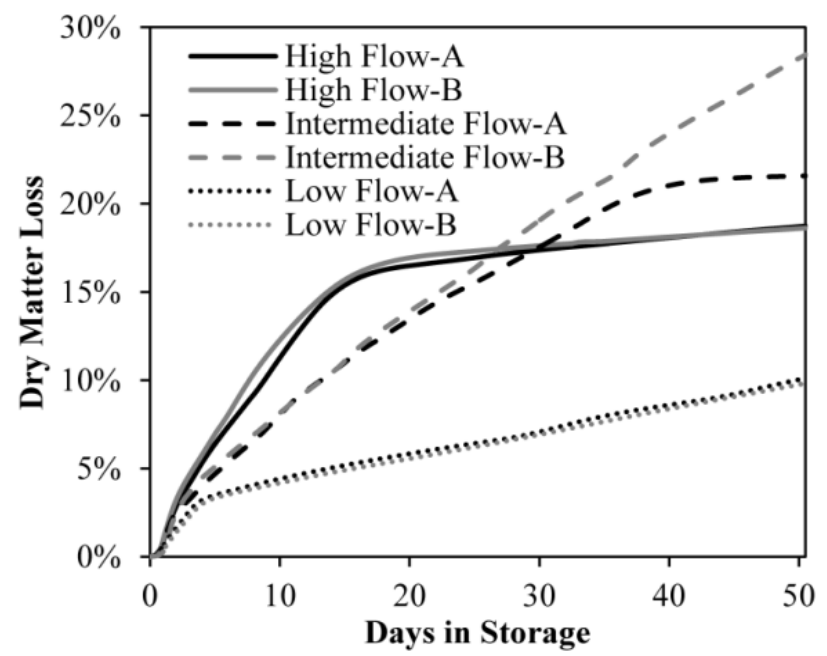

Figure 3. Dry matter loss of corn stover in storage reactors supplied with three airflows over 50 days in storage

The practice of bale wrapping greatly reduces oxygen availability in low density biomass and has been demonstrated to result in dry matter losses of less than 5\% in high moisture corn stover bales [2]. A collaboration between INL and POET Biomass in 2009 demonstrated that bale wrapping must be performed using the correct number of wraps to exclude oxygen and stack placement must direct water away from the stack or significant damage can occur [3]. Wrapping with fewer than the necessary wraps to promote anaerobic conditions only retains moisture within the bales and promotes biological degradation.

Current research supports the concept and practice of farm-scale anaerobic storage of wet corn stover biomass to promote long-term feedstock stability. Research has shown low dry matter losses, minimal change in composition, and conversion performance of wet anaerobically-stored corn stover $[4,5]$. Feedstock may be stored anaerobically in two formats: wrapped bales or bulk. Bulk feedstock may be stored anaerobically in sealed bags or tubes, in bunkers or piles, or in enclosures such as silos or bins. We chose to examine tube silage and drive-over piles as they represent anaerobic storage formats that may be employed on-farm with less investment in storage infrastructure than bunkers or enclosures. The goal is to examine operational choices that may be made by producers depending upon the current crop and climate conditions as they vary from season-to-season.

The following scenarios are compared in this milestone:

Conventional dry bale case: Multi-pass corn stover bales (30\% moisture, w.b.) stacked $4 \times 4$ and stored under tarp

Case \#1: Single-pass corn stover bales (45\% moisture, w.b.) stacked 4x4 and stored under tarp 
Case \#2: Single-pass corn stover bales (45\% moisture, w.b.) stacked 1x3 and bale-wrapped Case \#3: Single-pass chopped corn stover (45\% moisture, w.b.) collected in bulk and stored in silage tubes

Case \#4: Single-pass chopped corn stover (45\% moisture, w.b.) collected in bulk and stored in a drive-over silage pile

Operational activities, equipment, costs, and efficiencies are modeled based upon annual feedstock requirements using INL's Biomass Logistics Model (BLM). Model parameters, detailed equipment specifications, and case assumptions can be found in Appendix A-D. The costs for each scenario include harvest, collection, storage, and transportation to a centralized preprocessing facility. Preprocessing costs are omitted from this analysis due to 1) limited existing data on the costs and efficiencies of highmoisture corn stover size reduction and 2) because end-user specifications will vary based on individual refinery needs (i.e., desired particle size and moisture content).

\section{Key Parameters}

The 2012 NREL Biochemical Design requires an annual feedstock demand of 800,000 dry matter tons in order to supply a $61 \mathrm{M}$ gallon/year biochemical ethanol plant [6]. The INL BLM model assumes a supply area based on $50 \%$ of the acres in the area are arable, $50 \%$ of the arable acres are planted to corn, and $50 \%$ of the producers planting corn are delivering stover to the biorefinery. A 0.395 mile average haul distance was used for moving feedstock from the field to the on-farm storage site. This value was selected to provide one storage site for each approximately 630 acres harvested. A removal rate of 1.2 dry matter tons/acre is assumed in all cases. Land rent for storage is charged at $\$ 85 /$ acre per year for the storage format footprint. A $\$ 0.05$ per dry matter ton biomass feedstock insurance cost is charged for all cases. A $\$ 0.03$ per dry matter ton disposal charge is applied for wrapped bales and tube silage, which equates to a landfill tipping fee of approximately $\$ 30$ per ton for plastic disposal.

The conventional dry bale case relies on the moisture content no greater than $30 \%$ at the time of baling in order to keep dry matter losses at $12 \%$ or less in storage, as we have previously demonstrated in the storage reactors. A moisture content of $45 \%$ w.b. is assumed for the high moisture scenarios and is in the range possible for corn stover collected through single pass harvesting during grain harvest or during a wet harvesting season. While this moisture content is lower than the $60-70 \%$ moisture typically seen in silage, field demonstrations have shown that $45 \%$ moisture corn stover stored anaerobically experiences the same low dry matter loss as typically observed in silage [7].

\section{Conventional Dry Bale:}

The conventional dry bale case is based on multi-pass harvesting, windrowing, and baling. A flail shredding windrower is used to gather stover following grain harvest with a Class 7 combine operating at $70 \%$ efficiency (Case IH 7010). After field-drying to 30\% moisture, stover is formed into 3' x 4' x 8' large square bales (Hesston 2170 baler pulled by a Case IH Magnum tractor) at a density of $9.3 \mathrm{lb} / \mathrm{cu} \mathrm{ft}$ 
per bale dry basis. Bales are stacked in a 4 high by 4 wide $(4 \mathrm{x} 4)$ configuration using a self-propelled bale hauler (Stinger 6500) picking up 8 bales per load. Bales are placed field-side on unimproved ground and stored under a tarp to prevent moisture accumulation from precipitation. Bales are removed from storage throughout the year using a telehandler (Caterpillar TH220B with a bale spear) and then transported to a centralized preprocessing facility by a semi-tractor (Kenworth T800 3 axle-day cab) with a flatbed trailer (Fontaine Phantom 53') carrying 39 bales per load. Bales are secured and un-secured by the driver, and then unloaded at the facility with another Caterpillar TH220B telehandler.

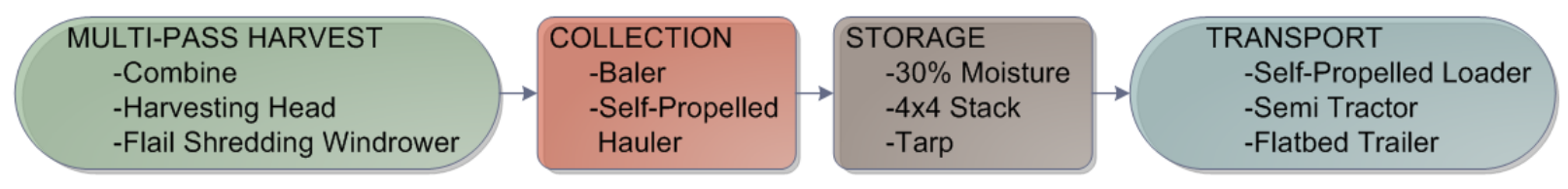

Figure 4. Conventional dry bale case

High-mositure bales; Cases \#1 and \#2:

The two high moisture bale cases in this milestone are based on the conventional dry bale case and are depicted in Figure 5. Single-pass harvesting, as opposed to multi-pass, allows material-other-than-grain (MOG) to pass directly into a large square baler being towed by the combine [8]. This harvesting method eliminates soil contact and results in lower stover ash content. However, it also eliminates field drying, which results in higher initial bale moisture content and thus presents a challenge to feedstock stability in storage.

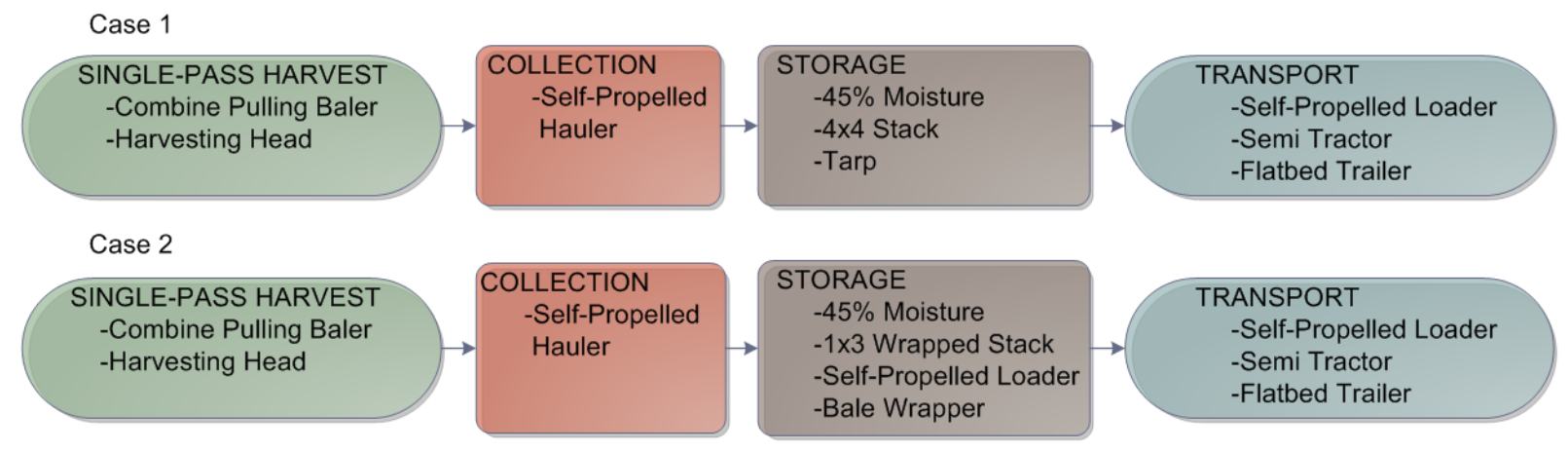

Figure 5. Baled storage cases

A Class 8 combine with additional horsepower (John Deere 9869 STS) was selected for use in the high moisture bale cases in order to pull the baler (Hesston 2170) while maintaining 70\% efficiency. As in the conventional dry bale case, 3' x 4' x 8' large square bales are made with a bulk density of $9.3 \mathrm{lbs} / \mathrm{cu} \mathrm{ft}$ (d.b.); however, the moisture content of the material is assumed to be $45 \%$ w.b.

In Case \#1, the bales are collected using a self-propelled bale hauler (Stinger Stacker 6500), assembled in a field-side 4 x 4 stack, and stored under tarp as in the conventional dry bale case. Dry matter losses in this case are assumed to be $25 \%$ over 6 months in storage. In Case \#2, bales are collected using a self- 
propelled bale hauler (Stinger 5500) and dropped adjacent to the bale wrapper. A telehandler (Caterpillar TH220B) then is used to feed the bale wrapper (Stinger 4000 Cube-Line Wrapper), resulting in a 3 bale high line of wrapped bales. Seven layers of wrap (50\% stretch factor, 50\% overlap) are used to limit oxygen exchange, reducing dry matter loss to $5 \%$. During recovery from storage, wraps are first cut manually and then the bales are removed from the plastic using a telehander (Caterpillar TH220B). Used wrap is assumed to be collected on site and disposed of in a local landfill.

As in the conventional dry bale case, bales in both Case \#1 and \#2 are transported to a centralized preprocessing facility by a semi-tractor with a flatbed trailer, and they are finally unloaded again at the preprocessing facility with a telehandler.

High-mositure bulk; Cases \#3 and \#4:

Cases \#3 and \#4 incorporate bulk collection, handling, and storage, as seen in Figure 6 . These scenarios include single-pass harvesting with a Class 8 combine (John Deere 9869 STS); material-other-than-grain (MOG) passes to the back the combine, which is equipped with a chopping unit similar in function to that of a forage chopper $[9,10]$. A co-located blower sends the stover to a forage wagon (Hesston model FB10) pulled alongside the combine by a tractor (Case IH Puma). Two tractor-wagon combinations are utilized to allow for continuous stover capture while full wagons are transferred to the storage site. The combine efficiency is reduced to $60 \%$ in the bulk wet cases to allow for the additional energy requirements of the forage chopping, which is consistent with field demonstrations [10]. The capital cost of the chopping mechanism is not captured in this report because this is still experimental in nature; additional capital equipment costs, albeit minimal, will be added to the harvesting costs of the wet scenarios when more mature data is available.
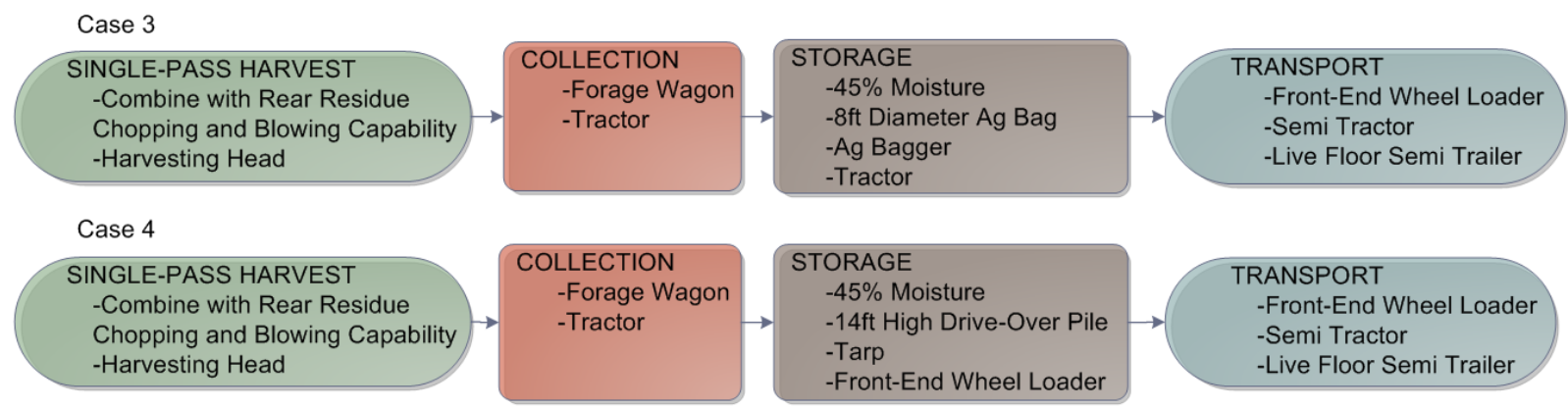

Figure 6. Bulk storage cases

Freshly harvest stover in the forage wagon is emptied using the floor chains, either directly into the AgBag in Case \#3 or into a pile in Case \#4. In Case \#3, $8 \mathrm{ft}$ diameter field-side storage bags are constructed using a tractor (John Deere 6115D) with a pull-behind bagger (Ag-Bagger G6070) and laid field-side on unimproved ground. The drive-over silage pile in Case \#4 is constructed on-farm by unloading forage wagons in a central location; the pile is a 14 foot high drive-over pile (136' by $139^{\prime}$ at the base) with a $20^{\circ}$ angle of repose [10]. The pile is formed and simultaneously compacted to $12.5 \mathrm{lb} \mathrm{DM} / \mathrm{cu} \mathrm{ft}$ using a wheel- 
loader (John Deere 624J) and covered with plastic tarps to limit oxygen infiltration. Dry matter losses of $5 \%$ is assumed in both bulk stover cases.

Silage in Cases \#3 and \#4 is recovered from storage using a wheel-loader (John Deere 624J) with a bucket attachement (Caterpillar M3; 3.9 cubic yard capacity) and loaded into a semi-tractor (Kenworth T800 3axle day cab) carrying a trailer with a live floor (Western Trailer Live Floor: 53' 2-axle) for easy unloading of bulk material at the preprocessing facility. Plastic is assumed to be removed and separated from the feedstock during recovery and set aside for disposal. The stover from an individual storage unit (silage bag or drive-over pile) is removed from storage at one time to minimize aerobic deterioration of the remaining tube or pile and eliminate silage facing operations in the pile.

\section{Results}

The INL Biomass Logistics Model was used to determine the costs for harvest, collection, storage, and transportation for each storage scenario; these costs are presented in Table 1.

Table 1. Modeled costs for each case by operation

\begin{tabular}{|l|l|l|l|l|}
\hline Scenario & $\begin{array}{l}\text { Harvesting and } \\
\text { Collection Cost, } \\
\$ / \text { ton, 2011\$ }\end{array}$ & $\begin{array}{l}\text { Storage Cost, } \\
\text { \$/ton, 2011\$ }\end{array}$ & $\begin{array}{l}\text { Transportation } \\
\text { Cost, } \\
\$ / \text { ton, 2011 }\end{array}$ & Total Cost \\
\hline Conventional bale & 33.24 & 6.68 & 22.23 & 61.15 \\
\hline Case \#1 Wet Bale & 23.95 & 10.50 & 26.79 & 61.24 \\
\hline Case \#2 Wrap & 22.84 & 9.80 & 24.99 & 57.63 \\
\hline Case \#3 Bag & 19.88 & 26.04 & 38.41 & 84.33 \\
\hline Case \#4 Pile & 19.88 & 15.81 & 38.41 & 75.97 \\
\hline
\end{tabular}

The total cost of the conventional bale and wet bale cases are nearly equivalent; reductions to cost using single pass harvesting are offset by cost increases 1) in storage as a result of dry matter loss and 2) in transportation due the additional weight of water. The draw radius is increased in both of these scenarios to provide 800,000 DMT/year while compensating for losses in dry matter (Table 2 and Appendix D).

Table 2. Resulting DML costs, land use, transportation distance, and cover use by case

\begin{tabular}{|l|l|l|l|l|}
\hline Scenario & $\begin{array}{l}\text { Storage DML } \\
\text { Cost, \$/ton, } \\
2011 \$\end{array}$ & $\begin{array}{l}\text { Storage Land } \\
\text { Area per site, } \\
\text { ac }\end{array}$ & $\begin{array}{l}\text { Transportation } \\
\text { Distance, miles }\end{array}$ & $\begin{array}{l}\text { Tarp, wrap, } \\
\text { or bag area } \\
\text { per site, } \mathrm{ft}^{2}\end{array}$ \\
\hline Conventional bale & 4.79 & 0.31 & 45.6 & 16,281 \\
\hline Case \#1 Wet Bale & 8.61 & 0.31 & 49.4 & 16,281 \\
\hline Case \#2 Wrap & 1.63 & 0.41 & 43.8 & 447,486 \\
\hline Case \#3 Bag & 2.30 & 0.88 & 43.8 & 288,343 \\
\hline Case \#4 Pile & 1.78 & 0.43 & 43.8 & 26,712 \\
\hline
\end{tabular}


Case \#2 is the most economical overall since it takes advantages of cost reductions of single-pass harvesting while maintaining low dry matter loss in storage due to wrapping; wrapping costs are reduced by stack wrapping. Transportation costs are higher than in the conventional case because the weight of the high-moisture bales reaches the maximum gross vehicle weight before the volumetric capacity is reached; however, overall costs are reduced in this scenario compared to Case \#1 because the draw radius, and thus transportation distance, is reduced.

The bulk storage scenarios have the lowest harvest and collection costs due to the single pass harvesting without the need for an expensive baling process. Modeled costs for bulk feedstock harvesting may be underrepresented, as no off-the-shelf equipment presently exists for a combine with stalk chopping and loading capabilities. However, given this potential weakness, the variables used in this analysis represent our best estimate using existing literature and personal communication with university researchers who have developed and tested this operational pathway (Stuart Birrell, personal communication). The storage costs for Case \#3 are high due to the increased land required for storage; ag-bags have larger footprint as a result of their low stacking height and their tendency to "slump" over time and expand from 8' to 12' in width. Transportation costs are approxamtely $50 \%$ higher for the bulk cases because 1 ) the bulk density of the silage is approximately half that of the high moisture bales and 2) because the semi-trucks are limited by the weight of the feedstock-associated water as opposed to being filled to volumetric capacity.

\section{Discussion}

The lowest total costs were for stack-wrapping wet bales field side (\$58/DMT). Stack wrapping was previously used in INL's 2009 herbaceous design [11], but was abandoned as a result of the observed degradation and unpredictability in storage performance seen in field trials in 2009 and 2010. It is important to note however that the mixed results in these cases may have been a result of wrapping with too few layers of plastic. In the case of 2010 only three layers were used because the goal of the study was to keep low moisture biomass dry, rather than keep high moisture biomass anaerobic. Because of this, sufficient moisture was able to enter the stacks and cause poor storage performance. In this study, the cost of wrapping is assumed at seven layers; the quantity recommended by commercial feed and forage operators. It is reasonable to assume that this rigorous wrapping method would prove more useful for keeping moisture out of dry materials as well as promoting anaerobic conditions as is the case of this research. Clearly, there is an advantage to stack wrapping where dry feedstock is not available and this practice is presently used, for example in states such as Minnesota, Wisconsin, Pennsylvania, and New York where cool, moist harvest conditions do not permit drying. The results of the cost analysis here show that stack wrapping may be a viable storage method in situations where feedstock moisture contents are high during corn harvest, either due to climate or adoption of single-pass technologies.

Tarp covered high-moisture single-pass bales experience significant DML, but improvements to harvest and collection costs match the storage and transportation costs associated with acquiring, storing, and moving more feedstock to replace that which was lost in storage. In this instance, there is no significant difference between the total costs prior to pre-processing. Questions remain regarding the impact of $45 \%$ 
versus $30 \%$ moisture content on the grinding costs. Pre-processing research at INL aims to resolve these costs and offer improvements to grinding performance for high-moisture feedstock.

Harvest and collection costs for bulk feedstock are lower than that of baled feedstock, a reflection of the cost of owning and operating a baler. However, transportation costs for low-density, high-moisture feedstock increase as a result of the need to run trucks at their volumetric capacity rather than the weight (mass) capacity. Costs for transportation for bulk feedstock increase to a greater degree than do the harvest and collection costs, likely another impact of low bulk density and the inefficiency of moving bulk material from the field into storage.

The bulk storage scenaros incur the highest total costs through harvest, collection, storage, and transportation. Harvesting bulk feedstock requires initial size reduction to improve bulk density and storage performance. However, if there are benefits to performing size reduction early in the supply chain, for example elimination of an operation in preprocessing, then the higher storage and transportation costs may be offset [12]. Potential for downstream cost reductions include elimination of first-stage grinding prior to drying and second-stage grinding. Preprocessing occurs at the refinery gate and costs an additional \$43.60/DMT (2011 \$/DMT) based on the conventional dry bale case, of which \$16.80/DMT is first-stage grinding. If in-field size reduction can attain conversion process size specification, then grinding and drying may be entirely eliminated for processes that are not sensitive to feedstock moisture content such as biochemical conversion and high-temperature liquefaction. However, these offsets need to be assessed specifically, since the costs of grinding and drying are dependent on both equipment and feedstock related details outside the scope of this harvest, collection, and storage analysis.

Anaerobic storage - ensiling — has been studied as a means to take advantage of the low $\mathrm{pH}$, which is a by-product of anaerobic fermentation, for partial pretreatment during storage [13]. Existing literature has demonstrated reduced pretreatment requirements for ensiled wheat straw [14] and increased sugar release during enzyme hydrolysis in ensiled barley straw [15]. Additionally, a study on whole crop maize silage indicated nearly $100 \%$ glucose recovery and $80 \%$ xylose recovery following hot water pretreatment, and nearly $100 \%$ conversion of sugars to ethanol [16]. Previous research in 2008 at INL demonstrated that ensiled corn stover, which sustained less than $2 \%$ dry matter loss, did not have a significant effect on the reactivity during dilute acid pretreatment. Additional research is needed to understand the effect of both aerobic and anaerobic storage on conversion efficiency. The conversion efficiency of corn stover in wet aerobic bale storage conditions, both in the field and in laboratory reactors, will be directly addressed in the Q4 milestone for this project and in FY15. Preliminary data indicates greater than $90 \%$ conversion of sugars following dilute acid pretreatment and enzymatic hydrolysis.

\section{Additional Considerations}

- Wet bales are notably difficult to handle as dry matter loss reduces their physical integrity, as we've noted in our field work to date. Problems in handling may increase mechanical dry matter loss; for example, if one bale in every 100 bales handled breaks prior to receipt at the biorefinery, the systemwide loss would increase by $1 \%$. Additionally, equipment engineered to handle a specific size and 
shape of bale may not function correctly when handling bales which have suffered such extensive dry matter loss (Tom Robb, Abengoa Bioenergy, personal conversation).

- Dry matter loss in the wrapped bale stack assumes maintenance of anaerobic conditions throughout storage. Previous research shows that insufficient or incomplete wrapping results in extensive dry matter loss. The current analysis assumes seven layers of wrap are sufficient to achieve the DML target of 5\%; Stinger recommends six to 10 layers for stack wrapped bales. If more layers are necessary to maintain storage stability expect storage costs to increase by $\$ 0.71$ per DMT (Justin Matlack, personal conversation) for the cost of wrap plus the additional costs for the reduction in bale wrapping efficiency - fewer bales wrapped per hour with a proportional increase in equipment operation, fuel, and labor costs.

- Bulk anaerobic storage is sensitive to oxygen infiltration. Ripped or punctured wraps result in damage and dry matter loss during storage. Coarse chopped corn stalks may present a greater risk to wraps than more finely chopped silage. Monitoring and repairing this damage requires producer time and effort, which has not been quantified in detail.

- Stack wrapping bales and tube wrapping silage require petroleum-derived polymer films that are used one time only. Wastes require disposal or recycling; these costs were estimated in our analysis. However, their impact on the GHG emissions may be significant [17] and should be considered in a LCA of these different supply options.

- Low-density high-moisture bulk feedstocks have increased transportation costs, and they also require the biorefinery to accept a greater number of trucks across the scale in a day. For example, if the biorefinery needs 2,286 DMT of feedstock per day the conventional dry bale case requires 24 trucks per hour, the wet bales (Cases \#1 and \#2) require 31 trucks per hour, and the wet bulk (Cases \#3 and \#4) require 40 trucks per hour. At a single scale house trucks will need to pass every 2:30, 2:00, and 1:30 minutes for dry bales, wet bales, and wet bulk respectively over an 8 hour shift, 6 days per week. Multiple scale houses and multiple plant access roads will likely be required to alleviate truck congestion around the plant. Expect truck unloading and feedstock handling demands to scale similarly.

- This analysis assumes that the theoretical ethanol yield of each feedstock post-storage remains unchanged. However, compositional changes have been documented in our research to date depending on the storage conditions.

- The organic acids produced during anaerobic storage may have cost implications on the conversion process. For example, high levels of acetic acid can be inhibitory to fermentation.

\section{References}

1. Wendt LM, Bonner IJ, Hoover AN, Emerson RM, Smith WA (2014) Influence of Airflow on Laboratory Storage of High Moisture Corn Stover. BioEnergy Research:1-11. doi:10.1007/s12155-0149455-3

2. Shinners KJ, Binversie BN, Muck RE, Weimer P (2007) Comparison of wet and dry corn stover harvest and storage. Biomass Bioenergy 31 (4):211-221

3. Smith WA, Bonner IJ, Kenney KL, Wendt LM (2013) Practical considerations of moisture in baled biomass feedstocks. Biofuels 4:95-110 
4. Shinners KJ, Wepner AD, Muck RE, Weimer PJ (2011) Aerobic and anaerobic storage of single-pass, chopped corn stover. BioEnergy Research 4 (1):61-75. doi:10.1007/s12155-010-9101-7

5. Tanjore D, Richard TL, Marshall MN (2012) Experimental methods for laboratory-scale ensilage of lignocellulosic biomass. Biomass \& Bioenergy 47:125-133. doi:10.1016/j.biombioe.2012.09.050 6. Humbird D, Davis R, Tao L, Kinchin C, Hsu D, Aden A, Schoen P, Lukas J, Olthof B, Worley M (2011) Process Design and Economics for Biochemical Conversion of Lignocellulosic Biomass to Ethanol. NREL Report No. TP-5100-47764.

7. Shinners KJ, Wepner AD, Muck RE, Weimer PJ (2011) Aerobic and anaerobic storage of single-pass, chopped corn stover. Bioenerg Res 4 (1):61-75

8. Birrell S, Karlen D, Wirt A (2014) Development of Sustainable Corn Stover Harvest Strategies for Cellulosic Ethanol Production. BioEnergy Research 7 (2):509-516. doi:10.1007/s12155-014-9418-8

9. Karlen DL, Birell SJ, Hess JR (2011) A five-year assessment of corn stover harvest in central Iowa, USA. Soil \& Tillage Research 115:47-55. doi:10.1016/j.still.2011.06.006

10. Shinners KJ, Bennett RG, Hoffman DS (2012) Single- and two-pass corn grain and stover harvesting. Transactions of the ASABE 55 (2):341-350

11. Hess JR, Wright CT, Kenney KL, Searcy EM (2009) Uniform-Format Solid Feedstock Supply System: A Commodity-Scale Design to Produce an Infrastructure-Compatible Bulk Solid from Lignocellulosic Biomass-Section 3: Pioneer Uniform-Format.

12. Brownell DK, Liu J, Hilton JW, Richard TL, Cauffman GR, Macafee BR (2012) Evaluation of two forage harvesting systems for herbaceous biomass harvesting. Trans ASABE 55 (5):1651-1658 13. Oleskowicz-Popiel P, Thomsen AB, Schmidt JE (2011) Ensiling - Wet-storage method for lignocellulosic biomass for bioethanol production. Biomass and Bioenergy 35 (5):2087-2092. doi:http://dx.doi.org/10.1016/j.biombioe.2011.02.003

14. Sipos B, Kreuger E, Svensson S-E, Réczey K, Björnsson L, Zacchi G (2010) Steam pretreatment of dry and ensiled industrial hemp for ethanol production. Biomass and Bioenergy 34 (12):1721-1731. doi:http://dx.doi.org/10.1016/j.biombioe.2010.07.003

15. Chen Y, Sharma-Shivappa R, Chen C (2007) Ensiling Agricultural Residues for Bioethanol Production. Applied Biochemistry and Biotechnology 143 (1):80-92. doi:10.1007/s12010-007-0030-7 16. Thomsen MH, Holm-Nielsen JB, Oleskowicz-Popiel P, Thomsen AB (2008) Pretreatment of WholeCrop Harvested, Ensiled Maize for Ethanol Production. Applied biochemistry and biotechnology 148 (13):23-33

17. Emery IR, Mosier NS (2012) The impact of dry matter loss during herbaceous biomass storage on net greenhouse gas emissions from biofuels production. Biomass and Bioenergy 39 (4):237-246 
Appendix A. Equipment list for SOT and four wet harvesting scenarios

\begin{tabular}{|c|c|c|c|c|c|c|c|c|c|}
\hline & Combine & $\begin{array}{l}\text { Harvesting } \\
\text { Head }\end{array}$ & Baler & $\begin{array}{l}\text { Forage } \\
\text { Wagon }\end{array}$ & $\begin{array}{l}\text { SP } \\
\text { Hauler }\end{array}$ & $\begin{array}{l}\text { Additional } \\
\text { Equipment }\end{array}$ & SP Loader & $\begin{array}{l}\text { Semi- } \\
\text { Tractor }\end{array}$ & Semi-Trailer \\
\hline $\begin{array}{l}\text { Conventional } \\
\text { Dry Bale Case }\end{array}$ & $\begin{array}{l}\text { Case IH } \\
7010\end{array}$ & $\begin{array}{l}\text { John Deere } \\
\text { 1293, } 12 \\
\text { Row @ 30" } \\
\text { Spacing; }\end{array}$ & $\begin{array}{l}\text { Hesston } \\
2170 \text { Lg } \\
\text { Sq } 36 " \text { X } \\
96 " ; \\
\text { CaselH } \\
\text { Magnum } \\
275 \text { HP }\end{array}$ & & $\begin{array}{l}\text { Stinger } \\
6500\end{array}$ & $\begin{array}{l}\text { Tarp; Blazer } \\
30 \mathrm{ft} \text { flail } \\
\text { shredder; } \\
\text { John Deere } \\
8230 \text { 245HP }\end{array}$ & $\begin{array}{l}\text { Caterpillar } \\
\text { TH220B } \\
\text { Telehandler; } \\
\text { Skid steer } \\
\text { bale spear }\end{array}$ & $\begin{array}{l}\text { Kenworth } \\
\text { T800 3-axle } \\
\text { day cab }\end{array}$ & $\begin{array}{l}\text { Fontaine } \\
\text { Phantom } \\
53 \text { ' Flat Bed } \\
\text { Trailer }\end{array}$ \\
\hline Case \#1 & $\begin{array}{l}\text { John } \\
\text { Deere } \\
9860 \text { STS }\end{array}$ & $\begin{array}{l}\text { John Deere } \\
1293,12 \\
\text { Row @ 30" } \\
\text { Spacing }\end{array}$ & $\begin{array}{l}\text { Hesston } \\
2170 \mathrm{Lg} \\
\text { Sq } 36^{\prime \prime} X \\
96 "\end{array}$ & & $\begin{array}{l}\text { Stinger } \\
6500\end{array}$ & Tarp & $\begin{array}{l}\text { Caterpillar } \\
\text { TH220B } \\
\text { Telehandler; } \\
\text { Skid steer } \\
\text { bale spear }\end{array}$ & $\begin{array}{l}\text { Kenworth } \\
\text { T800 3-axle } \\
\text { day cab }\end{array}$ & $\begin{array}{l}\text { Fontaine } \\
\text { Phantom } \\
\text { 53' Flat Bed } \\
\text { Trailer }\end{array}$ \\
\hline Case \#2 & $\begin{array}{l}\text { John } \\
\text { Deere } \\
9860 \text { STS }\end{array}$ & $\begin{array}{l}\text { John Deere } \\
1293,12 \\
\text { Row @ 30" } \\
\text { Spacing }\end{array}$ & $\begin{array}{l}\text { Hesston } \\
2170 \mathrm{Lg} \\
\text { Sq } 36^{\prime \prime} X \\
96 "\end{array}$ & & $\begin{array}{l}\text { Stinger } \\
5500\end{array}$ & $\begin{array}{l}\text { Stinger } 4000 \\
\text { Cube-Line } \\
\text { Wrapper } \\
(3 \times 4) ; \\
\text { Bale Wrap }\end{array}$ & $\begin{array}{l}\text { Caterpillar } \\
\text { TH220B } \\
\text { Telehandler; } \\
\text { Skid steer } \\
\text { bale spear }\end{array}$ & $\begin{array}{l}\text { Kenworth } \\
\text { T800 3-axle } \\
\text { day cab }\end{array}$ & $\begin{array}{l}\text { Fontaine } \\
\text { Phantom } \\
\text { 53' Flat Bed } \\
\text { Trailer }\end{array}$ \\
\hline Case \#3 & $\begin{array}{l}\text { John } \\
\text { Deere } \\
9860 \text { STS }\end{array}$ & $\begin{array}{l}\text { John Deere } \\
\text { 1293, } 12 \\
\text { Row @ 30" } \\
\text { Spacing }\end{array}$ & & $\begin{array}{l}\text { Hesston } \\
\text { forage wagon } \\
\text { model FB10; } \\
\text { CaselH Puma } \\
180 \text { HP MFD }\end{array}$ & & $\begin{array}{l}\text { Ag-Bagger } \\
\text { G6070; } \\
\text { John Deere } \\
6115 D, 115 \\
\text { HP }\end{array}$ & $\begin{array}{l}\text { John Deere } \\
624 \mathrm{~J} \text { Cat } \\
\text { bucket } \\
\text { loader (3M3 } \\
3.9 \mathrm{cu} \text { yard) }\end{array}$ & $\begin{array}{l}\text { Kenworth } \\
\text { T800 3-axle } \\
\text { day cab }\end{array}$ & $\begin{array}{l}\text { Western } \\
\text { Trailer "Live } \\
\text { Floor" 53' 2- } \\
\text { axle }\end{array}$ \\
\hline Case \#4 & $\begin{array}{l}\text { John } \\
\text { Deere } \\
9860 \text { STS }\end{array}$ & $\begin{array}{l}\text { John Deere } \\
1293,12 \\
\text { Row @ 30" } \\
\text { Spacing }\end{array}$ & & $\begin{array}{l}\text { Hesston } \\
\text { forage wagon } \\
\text { model FB10; } \\
\text { CaselH Puma } \\
180 \text { HP MFD }\end{array}$ & & $\begin{array}{l}\text { John Deere } \\
\text { 624J }\end{array}$ & $\begin{array}{l}\text { John Deere } \\
624 \mathrm{~J} ; \text { Cat } \\
\text { bucket } \\
\text { loader (3M3 } \\
3.9 \text { cu yard) }\end{array}$ & $\begin{array}{l}\text { Kenworth } \\
\text { T800 3-axle } \\
\text { day cab }\end{array}$ & $\begin{array}{l}\text { Western } \\
\text { Trailer "Live } \\
\text { Floor" 53' 2- } \\
\text { axle }\end{array}$ \\
\hline
\end{tabular}


Appendix B. Equipment parameter setting for bale harvesting scenarios

\begin{tabular}{|c|c|c|c|c|c|c|c|c|c|c|c|c|}
\hline & $\begin{array}{l}\text { Base } \\
\text { year }\end{array}$ & $\begin{array}{l}\text { List price } \\
\text { (\$) }\end{array}$ & Use Life $^{1}$ & $\begin{array}{l}\text { Salvage } \\
\text { value }\end{array}$ & $\begin{array}{l}\text { Horse } \\
\text { power } \\
\text { (hp) } \\
\end{array}$ & Capacity & $\begin{array}{l}\text { Field } \\
\text { Efficiency }^{1}\end{array}$ & $\mathrm{RM1}^{2}$ & $\mathrm{RM2}^{2}$ & $\mathrm{C1}^{1}$ & $\mathrm{C2}^{1}$ & $\mathrm{C3}^{1}$ \\
\hline $\begin{array}{l}\text { John Deere } 9860 \\
\text { STS }\end{array}$ & 2007 & 311,092 & 3,000 (hrs) & 0.29 & 375 & $\begin{array}{l}3000 \\
\text { (bu/hr) }\end{array}$ & $70 \%$ & 0.040 & 2.1 & 1.132 & 0.165 & 0.0079 \\
\hline $\begin{array}{l}\text { John Deere } \\
\text { 1293, } 12 \text { Row @ } \\
\text { 30" Spacing }\end{array}$ & 2007 & 69,251 & 2,000 (hrs) & 0.5 & & & & 0.040 & 2.1 & 1.132 & 0.165 & 0.0079 \\
\hline $\begin{array}{l}\text { Hesston } 2170 \text { Lg } \\
\text { Sq } 36 " \text { X 96" }\end{array}$ & 2007 & 109,824 & 3,000 (hrs) & 0.15 & & $\begin{array}{l}38 \\
\text { (bales/hr) }\end{array}$ & $80 \%$ & 0.100 & 1.8 & 0.852 & 0.101 & \\
\hline $\begin{array}{l}\text { Caterpillar } \\
\text { TH220B } \\
\text { Telehandler }\end{array}$ & 2006 & 69,414 & 10,000 (hrs) & 0.2 & 100 & $\begin{array}{l}80 \\
\text { (bales/hr) }\end{array}$ & $100 \%$ & 0.003 & 2.0 & 0.786 & 0.063 & 0.0033 \\
\hline Stinger $\mathbf{5 5 0 0}$ & 2006 & 139,000 & 14,500 (hrs) & 0.15 & 240 & $\begin{array}{l}83.3 \\
\text { (bales/hr) }\end{array}$ & $100 \%$ & 0.003 & 2.0 & 0.786 & 0.063 & 0.0033 \\
\hline $\begin{array}{l}\text { Stinger Stacker } \\
6500\end{array}$ & 2006 & 164,021 & 14,500 (hrs) & 0.15 & 240 & $\begin{array}{l}83.3 \\
\text { (bales/hr) }\end{array}$ & $100 \%$ & 0.003 & 2.0 & 0.786 & 0.063 & 0.0033 \\
\hline $\begin{array}{l}\text { Kenworth T800 } \\
\text { 3-axle day cab }\end{array}$ & 2006 & 110,809 & $1,000,000(\mathrm{mi})$ & 0.3 & 450 & & $100 \%$ & 0.003 & 2.0 & 0.976 & 0.119 & 0.0019 \\
\hline $\begin{array}{l}\text { Fontaine } \\
\text { Phantom 53' Flat } \\
\text { Bed Trailer }\end{array}$ & 2006 & 38,000 & $1,000,000(\mathrm{mi})$ & 0.9 & & $\begin{array}{l}26 \\
\text { (acre/hr) }\end{array}$ & & 0.003 & 1.5 & 0.786 & 0.063 & 0.0033 \\
\hline $\begin{array}{l}\text { Stinger } 4000 \\
\text { Cube-Line } \\
\text { Wrapper }(3 \times 4)\end{array}$ & 2006 & 40,000 & 3,000 (hrs) & 0.45 & 23 & $\begin{array}{l}80 \\
\text { (bales/hr) }\end{array}$ & $100 \%$ & 0.003 & 2.0 & 0.943 & 0.111 & \\
\hline
\end{tabular}

\footnotetext{
${ }^{1}$ Based on ASAE D497.7 MAR 2011 Table 3 - Field efficiency, field speed, and repair and maintenance cost parameters

${ }^{2}$ Based on ASAE D497.7 MAR 2011 Table 4 - Remaining value coefficients
} 
Appendix C. Equipment parameter setting for bulk harvesting scenarios

\begin{tabular}{|c|c|c|c|c|c|c|c|c|c|c|c|c|}
\hline & $\begin{array}{l}\text { Base } \\
\text { year }\end{array}$ & $\begin{array}{l}\text { List price } \\
\text { (\$) }\end{array}$ & Use Life $^{3}$ & $\begin{array}{l}\text { Salvage } \\
\text { value }\end{array}$ & $\begin{array}{l}\text { Horse } \\
\text { power }\end{array}$ & Capacity & $\begin{array}{l}\text { Field } \\
\text { Efficiency }^{3}\end{array}$ & $\mathrm{RM1}^{4}$ & $\mathrm{RM}^{4}$ & $\mathrm{C1}^{3}$ & $\mathrm{C2}^{3}$ & $\mathrm{C3}^{3}$ \\
\hline $\begin{array}{l}\text { John Deere } \\
9860 \text { STS }\end{array}$ & 2007 & 311,092 & 3,000 (hrs) & 0.29 & 375 & $\begin{array}{l}3000 \\
\text { (bu/hr) }\end{array}$ & $70 \%$ & 0.040 & 2.1 & 1.132 & 0.165 & 0.0079 \\
\hline $\begin{array}{l}\text { John Deere } \\
\text { 1293, } 12 \text { Row } \\
\text { @ 30" Spacing }\end{array}$ & 2007 & 69,251 & 2,000 (hrs) & 0.5 & & & & 0.040 & 2.1 & 1.132 & 0.165 & 0.0079 \\
\hline $\begin{array}{l}\text { Cat TH220B } \\
\text { Telehandler }\end{array}$ & 2006 & 69,414 & $\begin{array}{l}10,000 \\
\text { (hrs) }\end{array}$ & 0.2 & 100 & $\begin{array}{l}80 \\
\text { (bales/hr) }\end{array}$ & $100 \%$ & 0.003 & 2.0 & 0.786 & 0.063 & 0.0033 \\
\hline $\begin{array}{l}\text { Kenworth } \\
\text { T800 3-axle } \\
\text { day cab }\end{array}$ & 2006 & 110,809 & $\begin{array}{l}1,000,000 \\
\text { (mi) }\end{array}$ & 0.3 & 450 & & $100 \%$ & 0.003 & 2.0 & 0.976 & 0.119 & 0.0019 \\
\hline $\begin{array}{l}\text { Hesston forage } \\
\text { wagon mod. } \\
\text { FB10 }\end{array}$ & 2006 & 20,000 & 2,000 (hrs) & 0.3 & & $1350\left(\mathrm{ft}^{3}\right)$ & $80 \%$ & 0.160 & 1.6 & 0.943 & 0.111 & \\
\hline $\begin{array}{l}\text { John Deere } \\
\text { 6115D, } 115 \text { HP }\end{array}$ & 2008 & 46,989 & $\begin{array}{l}12,000 \\
\text { (hrs) }\end{array}$ & 0.36 & 115 & & $100 \%$ & 0.007 & 2.0 & 0.942 & 0.100 & 0.0008 \\
\hline $\begin{array}{l}\text { Ag-Bagger } \\
\text { G6070 }\end{array}$ & & & & & & & & & & 0.943 & 0.111 & \\
\hline $\begin{array}{l}\text { CaselH, Puma } \\
180 \text { hp MFD }\end{array}$ & 2008 & 115,803 & $\begin{array}{l}16,000 \\
\text { (hrs) }\end{array}$ & 0.36 & 180 & & $100 \%$ & 0.007 & 2.0 & 0.976 & 0.119 & 0.0019 \\
\hline $\begin{array}{l}\text { Western } \\
\text { Trailer "Live } \\
\text { Floor" 53' 2- } \\
\text { axle }\end{array}$ & 2007 & 75,000 & $\begin{array}{l}1,000,000 \\
\text { (mi) }\end{array}$ & 0.3 & 600 & $\begin{array}{l}1350 \\
\text { (tons/hr) }\end{array}$ & $70 \%$ & 0.003 & 1.5 & 0.786 & 0.063 & 0.0033 \\
\hline $\begin{array}{l}\text { John Deere } \\
\text { SPFH } 7850 \\
\end{array}$ & 2008 & 380,054 & 4,000 (hrs) & 0.31 & 245 & & $70 \%$ & 0.003 & 2.0 & 0.791 & 0.091 & 0 \\
\hline $\begin{array}{l}\text { John Deere } \\
\text { 624J }\end{array}$ & 2007 & 136,000 & 10,000 (hrs) & 0.2 & 167 & $\begin{array}{l}80 \\
\text { (bales/hr) }\end{array}$ & $100 \%$ & 0.003 & 2.0 & 0.786 & 0.063 & 0.0033 \\
\hline
\end{tabular}

\footnotetext{
${ }^{3}$ Based on ASAE D497.7 MAR 2011 Table 3 - Field efficiency, field speed, and repair and maintenance cost parameters

${ }^{4}$ Based on ASAE D497.7 MAR 2011 Table 4 - Remaining value coefficients
} 
Appendix D. Miscellaneous parameter setting for SOT and four wet harvesting scenarios

\begin{tabular}{|c|c|c|c|c|c|c|c|c|}
\hline & \multirow[t]{2}{*}{$\begin{array}{l}\text { Yield } \\
\text { (DMT/ ac) }\end{array}$} & \multirow[t]{2}{*}{$\begin{array}{l}\text { Moisture } \\
\text { (\%wb) }\end{array}$} & \multirow[t]{2}{*}{$\begin{array}{l}\text { DML } \\
\text { (\% init) }\end{array}$} & \multirow{2}{*}{$\begin{array}{l}\text { Annual } \\
\text { Demand } \\
\text { (including } \\
\text { DML } \\
\text { replacement } \\
\text { (DMT/yr) }\end{array}$} & \multicolumn{2}{|c|}{$\begin{array}{l}\text { Bulk Density } \\
\text { (Storage) }^{5} \\
\mathrm{lb} / \mathrm{ft}^{\wedge} 3\end{array}$} & \multicolumn{2}{|c|}{$\begin{array}{l}\text { Bulk } \\
\text { Density } \\
\text { (Truck) } \\
\text { lb/ft^3 }\end{array}$} \\
\hline & & & & & Dry & Wet & Dry & Wet \\
\hline 2013 SOT & 1.2 & 30 & 12 & 908,000 & 9.3 & 13.3 & 8.7 & \\
\hline Case \#1 & 1.2 & 45 & 25 & $1,066,000$ & 9.3 & 15.5 & 8.3 & \\
\hline Case \#2 & 1.2 & 45 & $5^{5}$ & 842,000 & 9.3 & 15.5 & 9.1 & \\
\hline Case \#3 & 1.2 & 45 & $5^{5}$ & 842,000 & 9.4 & 17.9 & 4.2 & 7.9 \\
\hline Case \#4 & 1.2 & 45 & $5^{5}$ & 842,000 & 8.1 & & 4.2 & 7.9 \\
\hline
\end{tabular}

\footnotetext{
${ }^{5}$ Shah, A., Darr, M. J., Webster, K. and Hoffman, C. (2011) “Outdoor Storage Characteristics of Single-Pass Large Square Corn Stover Bales in lowa” Energies, 4: $1687-1695$.
} 